\title{
The Effect of Blending Composition Against Latched Power and the Resistance of Batik Wax Against Cracking and Alkaline Chemicals
}

\author{
Nita Kusumawati ${ }^{\#}$, Anang Kistyanto ${ }^{*}$, Supari Muslim ${ }^{\$}$ \\ ${ }^{\#}$ Department of Chemistry, Universitas Negeri Surabaya, Ketintang, Surabaya, 60231, Indonesia \\ E-mail: nkusumawati82@yahoo.com \\ *Department of Economy, Universitas Negeri Surabaya, Ketintang, Surabaya, 60231, Indonesia \\ E-mail: anangkistyanto@gmail.com \\ ${ }^{\$}$ Department of Electrical Engineering, Universitas Negeri Surabaya, Ketintang, Surabaya, 60231, Indonesia \\ E-mail: supari.muslim@gmail.com
}

\begin{abstract}
On this research has been done the optimization of the batik wax waste utilization through batik wax making with blending method using bees wax, gum rosin, paraffin, and lard. This research has been expected to be able to reduce the water pollution along with the decline in the quantity of batik solid waste which has been discharged into water bodies. However, research needs to be done regarding the quality of batik product resulting from a production process using wax which involves the use of batik wax waste. The batik product quality is determined by latched power, and the resistance of the wax against cracking and alkaline chemicals of batik wax product which has been used. The latched power test results from four groups of batik wax product showed the area with minimum latched power on temperature range of 50-70 ${ }^{\circ} \mathrm{C}$ for batik wax which has been made from blending of bees wax, wax waste, and gum rosin, $50-80{ }^{\circ} \mathrm{C}$ for batik wax which have been made from blending of bees wax, wax waste, and paraffin; $50-90{ }^{\circ} \mathrm{C}$ for batik wax which have been made from blending of bees wax, gum rosin and lard. Compared with wax product which have been made from blend of bees wax, wax waste and gum rosin as well as with paraffin, the batik wax product which have been made from the blend of bees wax, gum rosin and lard have lower resistance to cracking that has been observed from the occurrence of yellow color on the fabric sample resulted from the dyeing process using yellow naphtol. The different result has been obtained from resistance test of the wax product against alkaline chemicals which showed that all kind of batik wax product resulted on this research have a good resistance against alkaline chemicals which has been observed from the absence of wax mass reduction of the fabric samples before and after treatment in the alkaline chemicals.
\end{abstract}

Keywords — batik; wax waste; bees wax; gum rosin; paraffin; lard

\section{INTRODUCTION}

Batik or wax resist dyeing is an Indonesian original ancient art that involves the dyeing process on fabrics using wax as a color barrier [1]-[2]. Batik has become an important textile product origin Java Indonesia which very famous. There has been a very long historical route of batik as a traditional and cultural heritage in Indonesia [3]-[4]. Now Indonesian batik has been recognized by UNESCO in the group "The Representative List of Intangible Heritage of Humanity generated by the Indonesian nation [4]-[5].

The process of batik making is inseparable from the art of the batik. There are so many things that must do in the batik wax making to get a high-quality wax. The weather will greatly affect the condition of batik wax. The proper formula of batik wax will produce a good quality wax, which is resisted and not easily fragile to chemicals, high on the resistance, elastic/limp, not easily cracks in any weather, obtaining the ornaments or motifs with the sharp lines, the wax cannot remove easily, the wax not leave the color on the fabric,easy to set, and not sticky, and also must be able to reused [4], [6].

After the dyeing process on the batik production completed, the wax generally must be immediately removed from the fabric through the heating process [7] and are generally directly disposed to water bodies as waste without any processing performed [8]-[9]. This is quite unfortunate given the reference [9] shows that the result from a functional group of batik wax waste which is done by Fourier Transform Infra Red (FTIR), no significant damage has been observed in the structure of the batik wax waste compound. It shows that the potential reuse of wax waste in the batik production process is still very high. 
Publications in reference [9] have proved it through the manufacturing of batik wax product with double component blending using the material of wax waste, gum rosin, paraffin, and lard. The results show that as many as 12 types of batik wax product have had optimum latched power and resistance against cracking and alkaline chemicals, so it is very potential to be commercialized immediately. However, as many as 4 types of batik wax still requires improved quality due to the low resistance against cracks, which was $20 \%$ wax waste (WW)/80\% gum rosin (GR); $100 \%$ paraffin (P), 20\% wax waste (WW)/80\% lard (L), and $100 \%$ lard (L).

Bees wax is a wax which is produced from beehives empty. The wax color is highly variable. Some are yellow or orange while the other are brownish. Bee wax is easily frozen and elastic at room temperature as well as easily broken in cold temperatures. Bee wax has a melting point $45-49{ }^{\circ} \mathrm{C}$, easily attached to the fabric, durable (not affected by climate), easy off with hot water [10].

Dice wax or wax waste is wax remnants which have been used before, separated from the water and has been through the freezing process. The physical properties include brown color towards black and have a melting point which little higher than bee wax (because usually mixed with elements of color remnants) [9], easy to dilute, easily remove from fabric. Dice wax has generally used in order to increase the wax melting point [4], [11].

Gum rosin is a residue of pine gum distillation (Casuarina equisetifolia/Pinus longaeva/Pinus Mercusii). The physical characteristic of gum rosin include transparent color (the darker more low quality), melting point $70-80^{\circ} \mathrm{C}$, needed a long time to melt, easy to penetrate the fabric pores, fragile or easy broken when getting treatment folded or bent, not resistant to alkali chemicals [4], [9].

Reference [9], [12] shows that the characteristic of Indonesian gum rosin similar with bee wax but with more complex molecular structure. This structure that caused its higher melting point of gum rosin compared with bee wax as well as dice wax, i.e., $86.73{ }^{\circ} \mathrm{C}$. Meanwhile bee wax and dice wax has a melting point each is $46.17{ }^{\circ} \mathrm{C}$ and $47.57{ }^{\circ} \mathrm{C}$. Gum rosin usually used as a wax blend in order to get the wax which has not frozen quickly, so it can be retrieved better pattern line sharpness.

The making of batik wax from a blend of bee wax, wax waste, and gum rosin material will produce batik wax with higher melting temperature compared with bee wax and wax waste, but lower compared to gum rosin material. In addition, the material blend of bee wax, wax waste, and gum rosin will produce a higher resistance of batik wax products concerned against cracks and alkaline chemicals.

Paraffin is an open-chain hydrocarbon and saturated with an alkane compounds. This substance is generally derived from petroleum [12], but now it can be obtained by synthesis. The physical properties are pure white color/light yellow, melting point $50-60{ }^{\circ} \mathrm{C}$, has a good resistance to wet penetrate, easy to dilute and quickly freezes, small adhesion, resistant to alkaline solution, although not durable [9], wax easily off or causing the waxes cracks [4]. Paraffin generally used as bee wax blend in order to produce batik wax material which has the good resistant power to wet penetrate.

The addition of bee wax and wax waste material into paraffin molten will lower the melting point of the paraffin material and produces a higher resistance against cracks. Thus, through the addition of bee wax and wax waste material into paraffin molten can be retrieved better pattern line sharpness and simultaneously produce batik wax which can be more easily removed from the fabric immediately after dyeing process completed.

Lard is animal fat or grease [13]. It is white like butter. Lard easily become diluted, and the melting point is $45^{\circ} \mathrm{C}$ $49^{\circ} \mathrm{C}$ [14] (usually has the lowest melting point compared than bee wax and dice wax). Lard usually used as a mixture of wax in a relatively small number in order to lower the melting point of the wax. In addition, lard is easily dislodged when has been removed from the fabric [4]. Lard is commonly used as a blend material of batik wax in order to get wax which is an easier to remove from the fabric after the dyeing process.

Different with the function of the addition of bee wax and wax waste material into gum rosin and paraffin molten, the blend of bee wax, wax waste, and lard will produce batik wax material with a lower melting point if compared to bee wax and wax waste.

The purpose of this research is to get the blending composition which is capable of producing batik wax product with optimum latched power and resistance to cracks and alkaline chemicals. It is important to be done in order to determine the expediency of batik wax products in question-related to the pattern or motive line sharpness of the desired, level of pattern cracking that allowed, the type of dye used and the weather when the batik production carried out.

\section{THE MATERIAL AND METHOD}

\section{A. Material}

The five main materials used in the manufacture of batik wax products from this research is bee wax (melting point $46,17^{\circ} \mathrm{C}$ ), batik wax waste (melting point $47,57^{\circ} \mathrm{C}$, obtained from Namiroh Batik SMEs Sidoarjo - Indonesia), gum rosin (melting point $86,73{ }^{\circ} \mathrm{C}$ ), paraffin (melting point $60,31^{\circ} \mathrm{C}$ ) and lard (melting point $45,21^{\circ} \mathrm{C}$ ). The materials needed for the quality test of wax include cotton fabric, yellow naphthol dyes, and diazonium salt (obtained from Namiroh Batik SMEs Sidoarjo - Indonesia), caustic soda ( $\geq 48 \%$, CV. Water Surabaya - Indonesia) and water. While the equipment needed for making and quality test of batik wax product include glass tools (pyrex), NESCO Lab MS-H280 Pro Magnetic Stirrer, PAJ1003 (Ohaus) analytical balance, thermometer (pyrex, max temperature $200^{\circ} \mathrm{C}$ ), and wax mold.

\section{B. Manufacture of Batik Wax}

In general, the making process of all type of batik wax on this step is done using the same stage, which is the melting stage of primary material (material with highest melting point) at its melting temperature and continued with melting stages of secondary batik wax material (material with lower melting point than primary material). The heating process is done until all of the batik wax materials is melted and evenly mixed. The process of batik wax ending with casting stage of batik wax molten and its drying process. In Table 1 seems 
the blend composition of batik was and operational conditions applied in the manufacture of batik wax.

TABLE I

BATIK WAX COMPOSITIONS AND ITS PREPARATION OPERATIONAL CONDITION

\begin{tabular}{|c|c|c|c|c|c|c|}
\hline \multirow[b]{2}{*}{$\begin{array}{l}\text { Batik } \\
\text { Wax } \\
\text { Type }\end{array}$} & \multicolumn{5}{|c|}{ Mass Percentage $(\%)$ in The Blend } & \multirow[b]{2}{*}{$\begin{array}{c}\text { Melting } \\
\text { Temperature } \\
\left({ }^{\circ} \mathrm{C}\right)\end{array}$} \\
\hline & 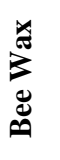 & 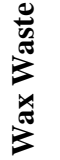 & 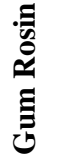 & 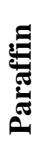 & 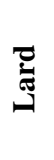 & \\
\hline W1 & 20 & 60 & 20 & 0 & 0 & 86.73 \\
\hline W2 & 20 & 40 & 40 & 0 & 0 & 86.73 \\
\hline W3 & 20 & 20 & 60 & 0 & 0 & 86.73 \\
\hline W4 & 20 & 0 & 80 & 0 & 0 & 86.73 \\
\hline W5 & 20 & 60 & 0 & 20 & 0 & 60.31 \\
\hline W6 & 20 & 40 & 0 & 40 & 0 & 60.31 \\
\hline W7 & 20 & 20 & 0 & 60 & 0 & 60.31 \\
\hline W8 & 20 & 0 & 0 & 80 & 0 & 60.31 \\
\hline W9 & 60 & 0 & 20 & 0 & 20 & 86.73 \\
\hline W10 & 40 & 0 & 20 & 0 & 40 & 86.73 \\
\hline W11 & 20 & 0 & 20 & 0 & 60 & 86.73 \\
\hline W12 & 0 & 0 & 20 & 0 & 80 & 86.73 \\
\hline
\end{tabular}

\section{Latched Power Test of Batik Wax}

To find out the maximum latched power of each wax products done testing that begins with the stage of fabrics sample coating by batik wax that will be tested using immersion method. The fabric sample that has been coated with batik wax subsequently drained for 24 hours. The latched power test is done through immersing of fabric samples that have been coated with batik wax in water at a temperature of $40-50{ }^{\circ} \mathrm{C}, 50-60{ }^{\circ} \mathrm{C}, 60-70{ }^{\circ} \mathrm{C}, 70-80{ }^{\circ} \mathrm{C}, 80$ $90{ }^{\circ} \mathrm{C}$, and $90-100^{\circ} \mathrm{C}$. The maximum latched power of batik wax can be known from the mass percentage of batik wax that has been released from fabrics samples at a specific temperature. The higher mass percentage of batik wax which released from fabric samples regardless of the heating process shows lower latched power of the batik wax on fabric samples.

\section{Cracking Resistance Test of Batik Wax}

To know the resistance of batik wax products against the cracks, on this stage has been done the testing process by involving dyeing process using yellow naphtol which starting with the stage of fabric samples coating with immersion method.

Yellow naphthol dye and diazonium salts used prepared by dissolve 1.76 gram of naphthol and 0.62 gram of soda caustic soda in $200 \mathrm{~mL}$ boiling water. To ensure the formation of a homogeneous solution has been carried out stirring process using a magnetic stirrer for 5 minutes. Meanwhile, the making of naphthol salt solution done by dissolving 3 grams naphtol salt in $100 \mathrm{~mL}$ cold water (room temperature). As well as the manufacturing process of naphthol dyes, to ensure the formation of a homogeneous naphtol salt solutions done stirring with a magnetic stirrer for 5 minutes.

After naphthol dyes available are done immersion process of fabric samples measuring $1.5 \mathrm{~cm} \mathrm{x} 3 \mathrm{~cm}$ in $30 \mathrm{~mL}$ naphthol dyes for 30 minutes. Further, samples of the fabric through the drying process for 5 minutes. The dyeing process followed by immersing of the fabric samples in a salt solution for 30 minutes. After immersing in a salt solution, the fabric is dried by the air for 15 minutes. Dyeing process ends with drying process by sunlight for 15 minutes. The optimum resistance of batik wax against cracks can be known from its undetectable appearance of typical yellow color from yellow naphtol after batik wax releasing process.

\section{E. Alkaline Chemicals Resistance Test of Batik Wax}

In order to know the resistance of batik wax against alkaline chemicals done the following testing phases. Batik wax melted down at the melting temperature and the applied on the fabric sample measuring $1.5 \mathrm{~cm} \mathrm{x} 3 \mathrm{~cm}$ with immersing method. The fabric samples which have been coated with batik wax subsequently weighed and dried at room temperature to dry out ( 24 hours). After 24 hours, the fabric samples immersed in $30 \mathrm{~mL}$ of soda $(0.62$ gram of soda caustic in $200 \mathrm{~mL}$ of water) for 30 minutes and then dried for 24 hours. In the final stages, fabric samples weighted by analytical balance. Significant differences between the mass of batik wax on fabric samples before and after immersing process in caustic soda show the lower resistance of batik wax against alkaline chemicals.

\section{RESULT AND DISCUSSION}

\section{A. The Latched Power of Batik Wax}

Latched power is one of the main parameters determining the quality of batik wax. The optimum latched power will produce batik fabric products with high quality, includes a neat motive line, not cracked, and the dyeing results do not overlap each other. However, it should be noted that the optimum latched power is not maximum latched power but rather leads to the most approaching to the positive control namely bee wax. Latched power is too high it will be difficult for batik wax releasing process that must be performed after the dyeing process completed. It will certainly cause the use of the higher wax release temperature, whereas the use of the higher wax release temperature is potential for increased the colors fades on motives that are not covered by batik wax. And vice versa, the latched power is too low will cause batik wax is not able to give an adequate barrier to specific parts which is want to from the fabric when done dyeing process especially in the dyeing process that uses a high temperature (above room temperature). The condition can cause the occurrence of overlapping colors on one same section of the batik fabric.

Latched power test results of batik wax products shows that from four batik wax compositions made from blend of bee wax, wax waste and gum rosin material, wax W1, W2, and W3 indicate the maximum latched power up to temperatures of $50{ }^{\circ} \mathrm{C}$, while wax $\mathrm{W} 4$ shows maximum latched power up to temperatures of $60{ }^{\circ} \mathrm{C}$. It indicates that the decrease of gum rosin material levels which has higher bond energy than the bee wax have lowered the overall chemical bond energy in a blend of batik wax material made from bee wax, wax waste, and gum rosin.

This then causes a decrease in the temperature of the batik wax release with composition $20 \% \mathrm{WW} / 80 \% \mathrm{GR}$ on the 
reference [8] from temperature range $80-90{ }^{\circ} \mathrm{C}$ a range of $50-60{ }^{\circ} \mathrm{C}$ which occurs as a result of bee wax material adding. A decrease in the temperature of batik wax release of this type has shown an increase in the quality of the wax $20 \% \mathrm{WW} / 80 \% \mathrm{GR}$.

Compared to the batik wax made from a blend of bees wax, wax waste and gum rosin materials, the entire batik wax made from a blend of bees wax, wax waste, and paraffin material have a higher wax release temperature. It suggests that paraffin has stronger physical interactions against the fabric fibers compared with gum rosin. This fact is reinforced by the results of the research that shows the lower wax release temperature in batik wax products containing gum rosin compared to paraffin containing material though gum rosin has a higher melting temperature.

Appropriate test results data of latched power of batik wax products made from the blend of bees wax, wax waste, and paraffin, known that the addition of bee wax material into a molten of wax waste and paraffin material blends have lowered the temperature of batik wax release from the temperature range of $90-100{ }^{\circ} \mathrm{C}$ [8] into the range of 70-80 ${ }^{\circ} \mathrm{C}$ especially for batik wax with compositions dominated by the paraffin, and this wax release temperature lower on the other compositions which have lower levels of paraffin. The products of batik wax W5 and W6 even have wax release temperature comparable with beeswax used as a positive control. Thus, when viewed from the aspect of latched power, it can be said that the efforts to improve the product quality of batik wax in reference [8] has been successfully carried out.

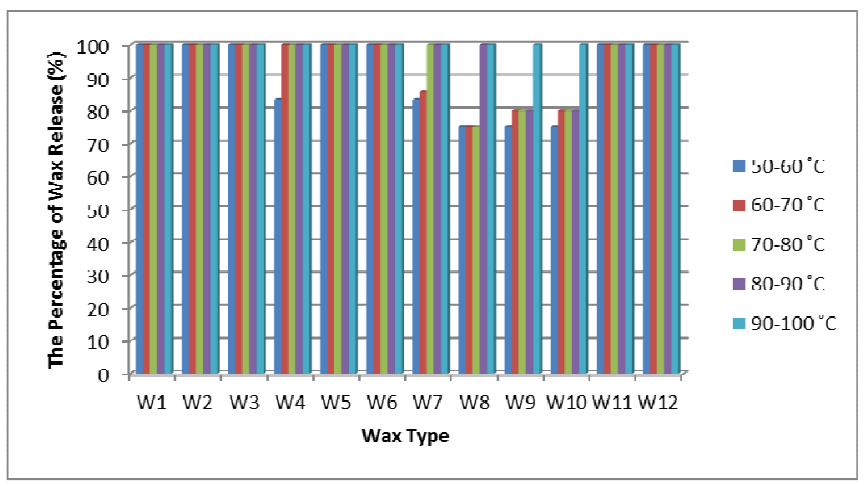

Fig. 1 Wax release percentage of a various wax type on specific temperature

Based on the data in Fig. 1, it is known that the addition of gum rosin into the material blend of wax waste and lard has improved the latched power of batik wax products $20 \% \mathrm{WW} / 80 \% \mathrm{~L}$ and $100 \% \mathrm{~L}$ in reference [8]. It can be seen from the increased temperature of the batik wax release made from a material blend of wax waste and lard in reference [8], from a temperature range of $70-80{ }^{\circ} \mathrm{C}$ be in the range of $90-100{ }^{\circ} \mathrm{C}$, especially in batik wax W9 and $\mathrm{W} 10$ as results of gum rosin addition. Meanwhile, the addition of gum rosin into batik with smaller wax waste levels or without the addition of wax waste, it is not observed an increase in latched power. The increased of the latched power showed that the addition of gum rosin had created a better physical interaction between batik wax compounds with cellulose fiber negatively charged. In Fig. 1 seems data of the wax release temperature of each batik wax products.

\section{B. The Resistance of the Batik Wax against Cracking}

The resistance of batik wax against cracking is a very important parameter in the production of batik fabric with high-quality motifs and color. The test results that show undetectable cracks on the entire composition of batik wax made from a blend of bees wax, wax waste, and gum rosin indicated that blending process is completed so that there was no insertion atomic arrangement which only lasted in parts of one field of atomic arrangement and produces line defects. Thus, it can be said that the efforts to improve product quality of batik wax $20 \%$ WW/ $80 \%$ GR in reference [8] has been successfully carried out.

The similar results obtained from cracking test result of batik wax product is made from the blend of bees wax, wax waste, and paraffin which shows that four batik wax compositions of this category entirely has good resistance to cracks. This is evident by the absence of yellow color occurrences on the fabrics sample that has been through the stages of the test using yellow naphthol dye. This condition indicates that the atomic rearrangement process which occurs in the blending process of bees wax, wax waste and paraffin has completed, so there is no appearance of line defects detected on batik wax structure that has been applied to the fabric sample.

Meanwhile, resistance to cracks that slightly lower shown by cracking test result of batik wax made from the blend of bees wax, gum rosin, and lard where not all types of this batik wax have a good resistance to cracks. Good resistance to cracks shown by products W9, W10, and W12. Meanwhile, the results of a test on batik wax W11 showed cracks on the structure of the wax that has been applied to the fabric sample. It indicated that increased levels of lard which is accompanied by declining levels of wax waste used have led to the domination of similar charge in the arrangement of the constituent material of batik wax that was dominated by the presence of lard. This condition has caused the occurrence of the atomic arrangement insertion events that are not perfect from one or more of the constituent material compound of batik wax W11.

TABLE II

Batik Wax Resistance Against CRacking

\begin{tabular}{|c|c|c|c|c|c|c|}
\hline \multirow[b]{2}{*}{$\begin{array}{l}\text { Batik } \\
\text { Wax } \\
\text { Type }\end{array}$} & \multicolumn{5}{|c|}{ Mass Percentage $(\%)$ in The Blend } & \multirow[b]{2}{*}{$\begin{array}{c}\text { The } \\
\text { Resistance } \\
\text { against } \\
\text { Cracking }\end{array}$} \\
\hline & 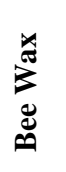 & 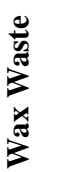 & 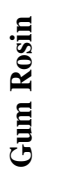 & 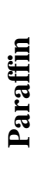 & 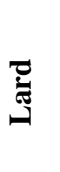 & \\
\hline W1 & 20 & 60 & 20 & 0 & 0 & Resistant \\
\hline W2 & 20 & 40 & 40 & 0 & 0 & Resistant \\
\hline W3 & 20 & 20 & 60 & 0 & 0 & Resistant \\
\hline W4 & 20 & 0 & 80 & 0 & 0 & Resistant \\
\hline W5 & 20 & 60 & 0 & 20 & 0 & Resistant \\
\hline W6 & 20 & 40 & 0 & 40 & 0 & Resistant \\
\hline W7 & 20 & 20 & 0 & 60 & 0 & Resistant \\
\hline W8 & 20 & 0 & 0 & 80 & 0 & Resistant \\
\hline W9 & 60 & 0 & 20 & 0 & 20 & Resistant \\
\hline W10 & 40 & 0 & 20 & 0 & 40 & Resistant \\
\hline W11 & 20 & 0 & 20 & 0 & 60 & Not resistant \\
\hline W12 & 0 & 0 & 20 & 0 & 80 & Resistant \\
\hline
\end{tabular}


The fact of similar charge domination on the atoms of the constituent material of batik wax W11 strengthened with research data that showed no detection of cracks on the structure of batik wax produced from a blend of gum rosin and lard which lard dominates. On this composition, even though levels of lard dominated $(80 \%)$ against the levels of gum rosin which much lower $(20 \%)$, but with the opposite charge of the gum rosin is much higher than lard has led the atomic insertion process in main atomic arrangement of batik wax W12 takes place more perfect compared to the atomic arrangement of batik wax W11. The data of batik wax resistance test results against cracks can be seen in Table 2.

\section{The Resistance of Batik Wax against Alkaline Chemicals}

The resistance to alkaline chemicals became one of the defining parameters of the batik wax products quality because generally the majority of batik SMEs in Indonesia, especially in Java Economic Corridors using a type of alkaline dye in the dyeing process of its batik fabric products. Therefore to get high-quality batik fabric product or has a good motive is necessary to know the resistance of the batik wax against the alkaline medium. The resistance which is not good at batik wax products will decrease the accuracy of batik process performed and trigger the appearance of colors on the motives that are not supposed.

The resistance test results of the batik wax products made from a blend of bees wax, wax waste, and gum rosin show that on the whole composition of batik wax products has a good resistance to alkaline chemicals which is known from undetectable peeling or batik wax lost from the fabric samples. Table 3 shows the results of the batik wax resistance test against alkaline chemicals. These results indicate that overall batik wax made from a blend of bees wax, wax waste, and paraffin materials has a resistance that is also good against alkaline chemicals. This shows that the existence of non-polar functional group on the batik wax product more dominating than the polar functional group thus causing a decrease in solubility of batik wax products in an alkaline solution which tends to be polar.

TABLE III

Batik Wax Resistance Against Alkaline Chemicals

\begin{tabular}{|c|c|c|c|c|c|c|}
\hline \multirow[b]{2}{*}{$\begin{array}{c}\text { Batik } \\
\text { Wax } \\
\text { Type }\end{array}$} & \multicolumn{5}{|c|}{ Mass Percentage $(\%)$ in The Blend } & \multirow[b]{2}{*}{$\begin{array}{l}\text { The } \\
\text { Resistance } \\
\text { against } \\
\text { Alkaline } \\
\text { Chemicals }\end{array}$} \\
\hline & 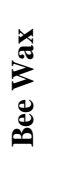 & 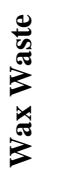 & 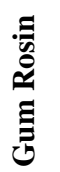 & ت & 胥 & \\
\hline W1 & 20 & 60 & 20 & 0 & 0 & Resistant \\
\hline W2 & 20 & 40 & 40 & 0 & 0 & Resistant \\
\hline W3 & 20 & 20 & 60 & 0 & 0 & Resistant \\
\hline W4 & 20 & 0 & 80 & 0 & 0 & Resistant \\
\hline W5 & 20 & 60 & 0 & 20 & 0 & Resistant \\
\hline W6 & 20 & 40 & 0 & 40 & 0 & Resistant \\
\hline W7 & 20 & 20 & 0 & 60 & 0 & Resistant \\
\hline W8 & 20 & 0 & 0 & 80 & 0 & Resistant \\
\hline W9 & 60 & 0 & 20 & 0 & 20 & Resistant \\
\hline W10 & 40 & 0 & 20 & 0 & 40 & Resistant \\
\hline W11 & 20 & 0 & 20 & 0 & 60 & Resistant \\
\hline W12 & 0 & 0 & 20 & 0 & 80 & Resistant \\
\hline
\end{tabular}

Similar results have also shown from the test results of batik wax made from a blend of bees wax, gum rosin, and lard material. The results of the test suggest that the overall composition of batik wax in this category have a good resistance to an alkaline solution. It is shown from the fact that showed the absence of peeling of the batik wax layer that has been applied to a fabric sample. The low solubility of batik wax in this category is due to the low ratio of the polar functional groups of a non-polar functional groups owned by a compound of batik wax materials from this category. In Table 3 it can be seen the batik wax resistance against alkaline chemicals.

\section{Batik Fabric Prototype}

On the stage of this research has been done applications of batik wax W1-W12 in batik process with real scale by involving experts from of Batik Tengah Sawah SMEs in Pacitan Indonesia. The batik fabric prototype resulting from batik process using batik wax W1-W4 appear in Fig. 2-5.

Visualization of batik fabric prototype manufactured a product with batik wax W1-W4 increasingly supporting the laboratory scale research data that has already been done before, where the quality of the resulting colors and motives in batik fabric prototype does not indicate the presence of cracks and the occurrence of color on the motive that are not supposed.

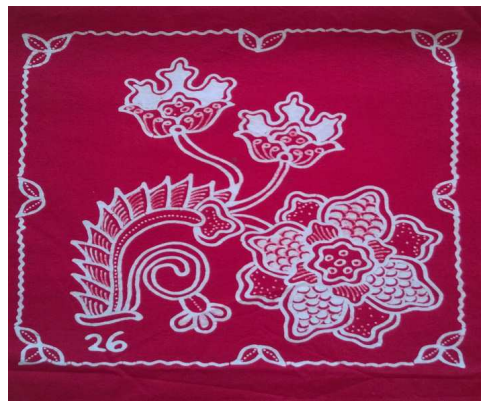

Fig. 1 Batik fabric prototype that uses batik wax W1

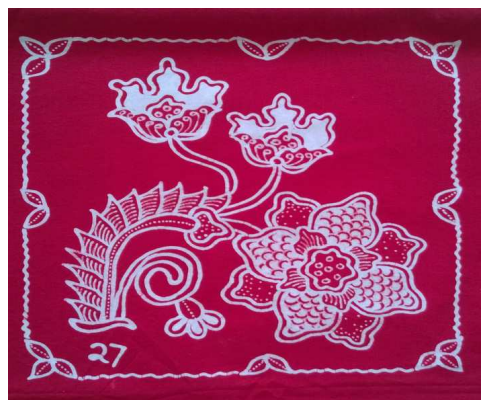

Fig. 3 Batik fabric prototype that uses batik wax W2

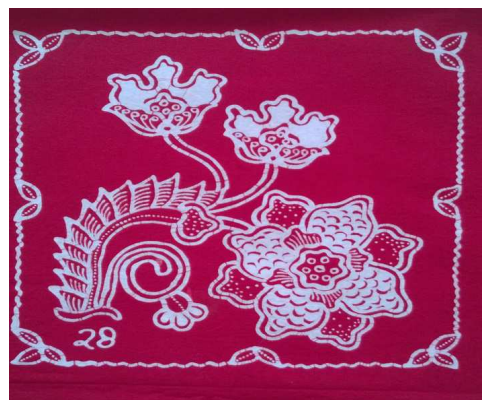

Fig. 4 Batik fabric prototype that uses batik wax W3 


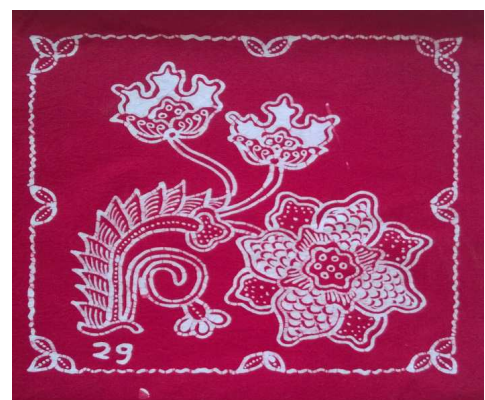

Fig. 5 Batik fabric prototype that uses batik wax W4

In Fig. 6-9 appears the batik fabric prototype manufactured with batik wax W5-W8. Based on visual in Fig. 6-9 seems that batik fabric prototypes produced by using batik wax of this category have good quality. It is proved by undetectable cracks on the motives, although current the cracks on the motives has been widely used as a new innovation in the production of batik fabric.

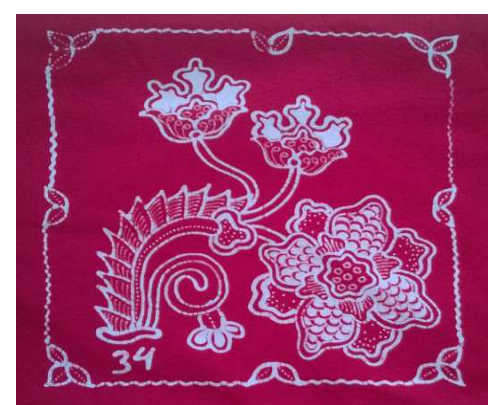

Fig. 6 Batik fabric prototype that uses batik wax W5

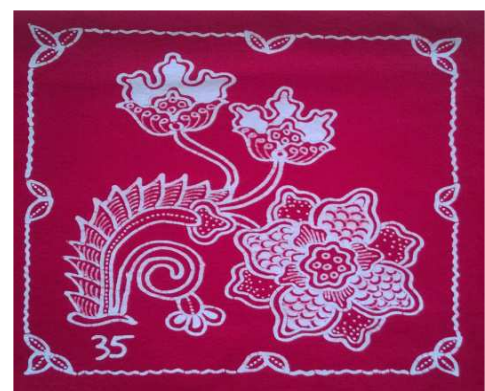

Fig. 7 Batik fabric prototype that uses batik wax W6

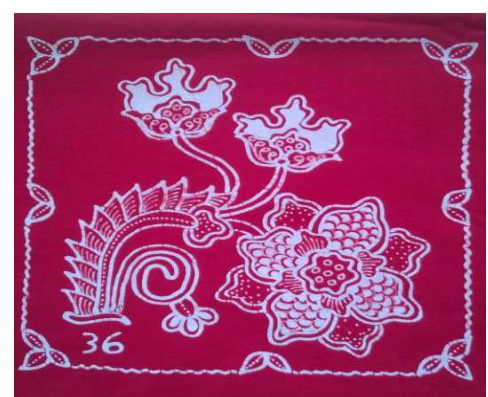

Fig. 8 Batik fabric prototype that uses batik wax W7

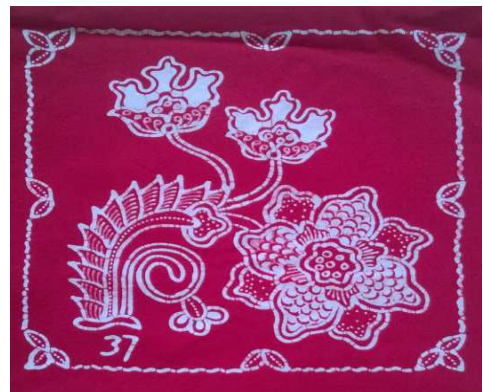

Fig. 9 Batik fabric prototype that uses batik wax W8

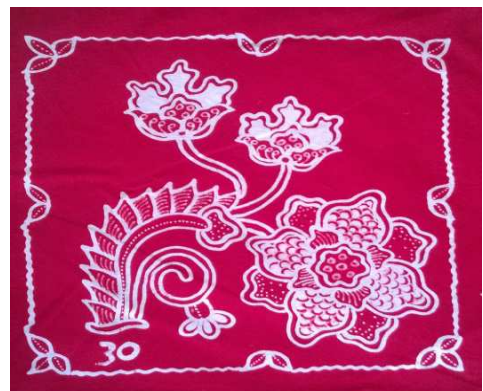

Fig. 10 Batik fabric prototype that uses batik wax W9

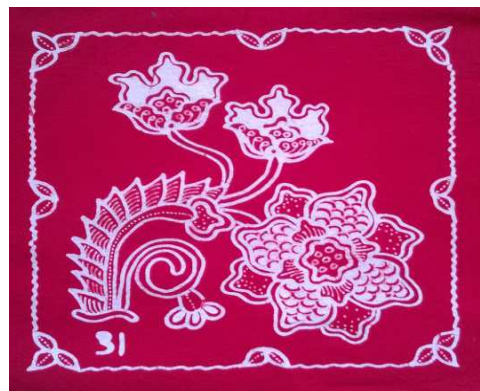

Fig. 11 Batik fabric prototype that uses batik wax W10

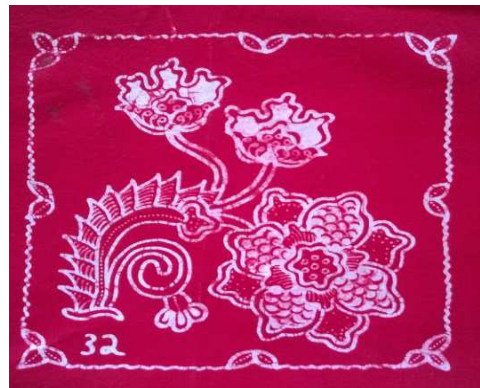

Fig.12 Batik fabric prototype that uses batik wax W11

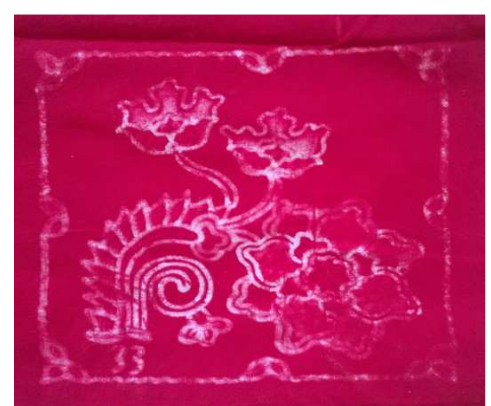

Fig. 13 Batik fabric prototype that uses batik wax W12

The application stage of batik wax W1-W12 is expected to become the embodiment of the direct invention of the research results by the perpetrators of batik business. More specific, this stage aims to know the difficulty level of batik 
wax products application in batik process with real scale on the field and knowing the quality of dye resist and dyeing that results from the batik process using batik wax products by experts in the field. In Fig. 10-13 appears the batik fabric prototypes was produced using batik wax W9-W12. The observation result of batik fabric prototypes are manufactured using batik wax products in this category demonstrates high quality on motives line and dyeing as a result of the use of batik wax W9 and W10. While in Fig. 11 and Fig. 12 appears typical cracks of the batik wax W11 dan W12.

Although the analysis result from laboratory scale showed a high resistance of batik wax W12 against crack and alkaline solution, the real scale deployment results showed a high level of difficulty in batik process that involves this type of wax, because of its lower penetrating power at fabric fiber. On Table 4 shows the quality of each batik fabric prototype resulting from the production process using batik wax W1-W12.

TABLE IV

THE QUALITY OF BATIK FABRIC PROTOTYPE

\begin{tabular}{|c|c|c|c|}
\hline \multirow{2}{*}{$\begin{array}{c}\text { Batik } \\
\text { Wax } \\
\text { Type }\end{array}$} & $\begin{array}{c}\text { Batik Fabric Parameters } \\
\text { against } \\
\text { Cracking }\end{array}$ & $\begin{array}{c}\text { The } \\
\text { Resistance } \\
\text { against } \\
\text { Alkaline } \\
\text { Chemicals }\end{array}$ & $\begin{array}{c}\text { The Quality } \\
\text { of Batik } \\
\text { Fabric } \\
\text { Prototype }\end{array}$ \\
\hline W1 & Resistant & Resistant & Good \\
\hline W2 & Resistant & Resistant & Good \\
\hline W3 & Resistant & Resistant & Good \\
\hline W4 & Resistant & Resistant & Good \\
\hline W5 & Resistant & Resistant & Good \\
\hline W6 & Resistant & Resistant & Good \\
\hline W7 & Resistant & Resistant & Good \\
\hline W8 & Resistant & Resistant & Good \\
\hline W9 & Resistant & Resistant & Good \\
\hline W10 & Resistant & Resistant & Good \\
\hline W11 & Not Resistant & Resistant & Fair \\
\hline W12 & Not Resistant & Not Resistant & Poor \\
\hline
\end{tabular}

\section{CONCLUSIONS}

Based on the quality test results performed on batik wax W1-W12, can be concluded some things: The addition of bees wax to a blend of wax waste and gum rosin has generated batik wax W1-W4 with a good latched power and resistance to cracks and also alkaline chemicals. The addition of bees wax to a blend of wax waste and paraffin has generated batik wax W5-W8 with a good latched power and resistance to cracks and also alkaline chemicals. Manufacture of batik wax products from a blend of bees wax, gum rosin and lard has produced batik wax W9-W10 with a good latched power and resistance to cracks and also alkaline chemicals. While the typical pattern of cracks observed from batik process results using batik wax W11 and W12.

\section{ACKNOWLEDGMENT}

We would like to thank Direktorat Penelitian dan Pengabdian Masyakarat Kementrian Riset dan Teknologi Pendidikan Tinggi Republik Indonesia which has provided financial support through National Priority Research Programme Masterplan of Acceleration and Expansion of Indonesia Economic Development.

\section{REFERENCES}

[1] McCabe Elliot. Batik, Fabled Cloth of Java. Jakarta, Indonesia: Periplus, 2004.

[2] W. Pancapalaga, P. Bintoro, Y.B. Pramono, S. Triatmojo, "The evaluation of dyeing leather using batik method," International Journal of Applied Science and Technology, vol. 4(2), pp. 236, 2014.

[3] Hasanudin. Batik Pesisiran: Melacak Pengaruh Etos Dagang Santri pada Ragam Hias Batik. Bandung, Indonesia: Kiblat Buku Utama, 2014.

[4] K. Kudiya, S. Sabana, A. Sachari, "The waxing optimization in finding the best melting point of wax for staining Cirebon Batik, “Arts and Design Studies, vol. 20, pp. 10, 2014.

[5] A. Iriani, S.H. Priyanto, "Modeling of employee relationships in SME batik: case study of Windasari Batik," Asian Journal of Management Sciences and Education, vol. 2(4), 2013.

[6] L. Shi and L. Xing, "Circular economy: a new development strategy for suistanable development in China," in Proc. Third World Congress of Environmental and Resource Economists, Japan, 2006.

[7] A.E. Asmah, V. Okpattah, and S.T. Daitey, "The innovative wet dyeing t-shirt technique," International Journal of Academic Research and Reflection, vol. 4(1), 2016.

[8] N. Kusumawati, T. Koestiari, A.B. Santoso, "The influence of washing process using TRO on indigosol dyeing quality, leaching percentage, and mechanical strength of mori fabric," Res. J. Pharm. Biol. Chem. Sci., vol 6(4), pp. 55-63, 2015.

[9] N. Kusumawati, S. Muslim, A. Kistyanto, D. Arifiana, "Optimization of batik was waste reutilization by blending method using gum rosin, paraffin, and lard on handmade batik fabric production towards zero waste management," Res. J. Pharm. Biol. Chem. Sci., vol 7(2), pp. 55-65, 2016.

[10] Susanto, S.K. Sewan, Seni kerajinan batik Indonesia. Yogyakarta, Indonesia : Balai Penelitian Batik dan Kerajinan, Lembaga Penelitian dan Pendidikan industry, Departemen Perindustrian RI, 1980.

[11] C.A. Sheares, "The batik patterning technique in Southeast Asia," The Heritage Journal., vol. 4, pp. 97-129, 2009.

[12] A. Plotto, and B. Baker, "A review of wax-based and other coatings for fruits and vegetables," USDA-ARS, Citrus and Subtropical Products Laboratory, Winter Haven, FL and Organic Materials Review Institute, Eugene, OR., IFOAM Tech. Paper, 2005.

[13] Centrec Consulting Group, "Biodiesel demand for animal fats and tallow generates an additional revenue stream for the livestock industry," Centrec Consulting Group, The National Biodiesel Board Tech. Paper, 2014.

[14] Manual of methods of Analysis of Foods : Oils and Fats, Food Safety and Standards Authority of India, 2012. 